\title{
INNOVATION POLICY FEATURES IN THE OECD COUNTRIES
}

\author{
Ivan ANISIMOV', \\ Donetsk National University (Vinnitsa), Ukraine
}

\begin{abstract}
The purpose of the paper is to analyze the innovation policy features in the OECD countries and give the basic framework which defines rights and obligations of intellectual property rights (IPRs) owners. Governments play an important role in determining demand-side policies, such as smart regulations, standards, consumer education, taxation and public procurement that can affect innovation. Because demand linked to supply, policies that affect both need to be better harnessed to drive long-term innovation and sustainable growth. Policies to stimulate innovation require taking account of changes in the international economy and the transformation of innovation processes. To transform invention into innovation requires a range of activities. Innovation now encompasses much more than research and development (R\&D), albeit R\&D remains vitally important. Methodology. The data for the paper is taken from the publications and reports of the European Commission, OECD, World Bank etc. In the paper the descriptive analysis, supported by the quantitative analysis is applied. Results. It is identified that rises in R\&D intensity and innovation are driven by such factors: reduction of anti-competitive market regulations, which promotes business R\&D and strengthens the incentives for innovations; stable economic conditions and low interest rates which encourage the growth of inno vation activity by creating a low-cost environment for investment in innovation; availability of internal and external finance. Practical implication. It is given the basic legal framework which defines rights and obligations of IPR owners: reviewing exemptions to copyright in the light of the internet's different uses; clarifying exemptions for research use; promoting an active and open commercialization policy for universities; encouraging the commercialization and monetization of IPR: for example draft licensing contracts, valuation standards; standards: encouraging pooling mechanisms, platforms etc.; accelerating patent processing while preserving quality. Value/originality. Received conclusions will help to understand the innovation policy features in the OECD countries what gives an opportunity to use their experience in Ukraine.
\end{abstract}

Key words: innovation policy, intellectual property rights (IPRs), innovation activity, knowledge and technology transfer, R\&D expenditures.

JEL Classification: F43, O31, O32, 034

\section{Introduction}

The ability to innovate and to bring innovation to market will be an important determinant of the global competitiveness over the future decade. There is growing awareness among politics that innovative activity is the main engine of economic progress as well as a potential factor in meeting global challenges in spheres such as the environment and health.

Not only has innovation moved to center-stage in economic policy making, but there is a realization which requires a coherent, "whole-of-government" approach. Many OECD countries have adopted national strategies to foster innovation and improve its economic impact. Even countries that have refrained from active industrial policy last years now seek new ways to improve the environment for innovation with the aim to boost productivity and growth. The USA for example, came forward with the "Innovate America" strategy in 2005 (A strategy, 2005). The EU's "Lisbon Agenda”, prepared in 2000, has today been updated and strengthened (The Lisbon strategy, 2000).

Governments could also play a more direct role in enhancing innovation. Public investment in science and research can play an important role in developing ICT and other technologies and in enabling further innovation. This shows the importance of reforming the management and funding of investment in science and technologies, as well as public support to innovative activity in the private sector. The latter calls for a mix of direct and indirect instruments (tax credits, direct support and publicprivate partnership) support for innovative clusters and rigorous evaluation of such public support.

\footnotetext{
Corresponding author:

${ }^{1}$ Department of International Economics Assistant, Donetsk National University (Vinnitsa).

E-mail: music23@mail.ru
} 


\section{Policy problems and challenges}

Much of the rise in living standards is thanks to innovation - this has been the argument since the Industrial Revolution. Nowadays, innovative performance is an important factor in determining competitiveness progress. Besides, innovation is important to help address global challenges, for example, climate change and sustainable growth and development.

But it is the application of advances in technology, in addition with innovative approaches to the creation of goods and services, which translates scientific advances into more productive economic activity. This results in economic growth if market structures and the environment enable the more productive activities to expand.

Innovative effort is on the rise as a part of economic activity. Investment in knowledge has grown more quickly than investment in industry and equipment since the 1990-s in most OECD countries, and has surpassed the latter in a few countries such as the USA and Finland. $\mathrm{R} \& \mathrm{D}$ intensity of the economy has risen in a number of smaller OECD members, but remains more or less unchanged in the OECD area as a whole since 1995, and cross-country differentials remain (Figure 1).

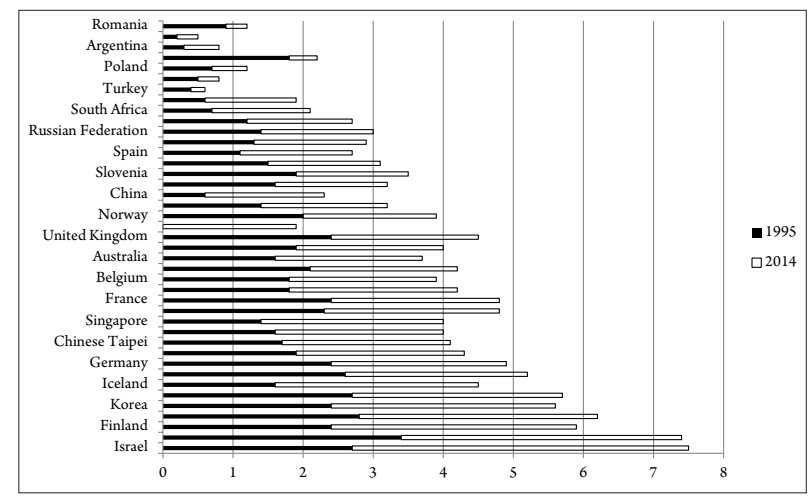

Source: (Innovation and growth, 2007, see p. 7)

Fig. 1. Growth in R\&D expenditures in OECD countries in $1995,2014, \%$

But intellectual assets are rapidly becoming the instrument of value creation through a number of channels. Improvements in the skill composition of labor play a huge role in productivity rising.

Investment in $\mathrm{R} \& \mathrm{D}$ is associated with high rates of potential profit. And investments in software have also contributed to business performance and economic growth, accounting for as much as one-third of the contribution of ICT (information and communications technology) capital to GDP growth since 1995 in France, Denmark, Sweden, the Netherlands and the USA (OECD, 2007).

The importance of innovation has been reinforced both by globalization and by advances in new technologies, which have enabled new competition forms and opened new markets for the creation of innovative goods and services. Besides globalization has increased the pressure on OECD countries to move up the value chain and engage in a process of adjustment and innovation.

There has been a significant rising in R\&D effort in a number of economies outside the OECD area (Figure 1), and, although starting from a low base, the associated growth of R\&D capabilities in a number of major developing economies is making them competitive destinations for cross-border R\&D. At least China is now a key global player in $\mathrm{R} \& \mathrm{D}$ in indicators of absolute size as well as growth rates, with Gross Expenditure in R\&D reaching USD 115 billion in 2005 (at PPP s), compared to USD 227 billion in the EU (provisional) or USD 118 billion in Japan in 2005 (OECD, 2006).

Recent OECD analysis has shown that rises in R\&D intensity and innovation are driven by such factors.

Reduction of anti-competitive market regulations, which promotes business $\mathrm{R} \& \mathrm{D}$ and strengthens the incentives for innovations. Besides, a low level of restrictions on foreign investment is important, as it can improve international knowledge transfers.

Stable economic conditions and low interest rates which encourage the growth of innovation activity by creating a low-cost environment for investment in innovation.

Availability of internal and external finance.

An expansion in public research, which can support business sector research, albeit expanding both at the same time, will need efforts to raise the supply of labor force.

Fiscal incentives. Tax impact for private $R \& D$ is often found to provide a stronger incentive to business $R \& D$ than direct government support. This may be because much direct support for R\&D is permitted at meeting government goals, such as energy security or defense, and not at promoting private $R \& D$.

Openness to foreign $\mathrm{R} \& \mathrm{D}$, which is connected with higher productivity growth, especially when domestic $\mathrm{R} \& \mathrm{D}$ investment and capabilities are high too (OECD, 2006).

\section{The importance of intellectual property rights (IPR) for innovation activity}

The important policy question remains how to set an appropriate balance between incentives and rewards to inventors and providing access to knowledge for users. Over the recent years the balance has been shifting in favor of holders, at least in reaction to changing conditions but also as a deliberate move towards "pro-IPR policies" ("prointellectual property rights policy"). These policies have resulted in achievements, such as the progress of technology and knowledge transfers from universities and institutes in countries which have promoted patenting of public research; the expansion of the biotech sphere, which would have been hardly possible without patents on genetic innovations; and the multiplication of venture capital based startups, which often rely on intellectual property rights.

As the policy, legal and economic environment are still evolving, the situation in the sphere of IPR is not stabilized. 
Public debates have turned around the efficiency and distributive impacts of consolidating IPR regimes. If strong IPR are required with the aim to give incentives for creative activities, they have not on the other hand endow the holder with such rights as to block all access to new technologies and knowledge.

Difficulties have emerged in the following areas.

Access to innovations for research use (biotech) or for further improvement have been hampered by patents in a number of cases, hence slowing down research.

Establishment of standards for interoperability and other use of IPR have been delayed or made more costly by strategies based on IPR.

The reserve at most patent offices has exploded, creating uncertainty on a vast scale, while there have been concerns about the quality of patents.

The extension of digital rights management (DRM) systems is meeting with resistance as they put restrictions on the rights of consumers, hence reducing the scope of "fair use" of copyright law, for example.

No satisfactory formula has been found for ensuring that inventors are rewarded while fully using the fluidity suggested by the Internet.

In the context of the changing environment for innovation, it is important to review the IPR system and practices to assess whether it continues to promote innovation and provide access to knowledge base, or if in certain cases the degree of control with which IPR owners are endowed could complex competition, use and the technology transfer. The new innovation environment suggests opportunities that could be seized more efficiently if the IPR system is adapted so as to become more flexible and play new roles in the economy. Recent developments in the IP environment include.

The progress of different types of "open modes" of innovation where knowledge flows between firms and between firms and universities, has increased the need for protection and strengthened the potentially damaging effects of excessive protection, which could complex access by third players. Essentially, sharing is easier when there is a framework for incentives.

As companies rely on inventions made by others, the number of licensing deals has grown, which strengthens the necessity for the technology market to be built on solid grounds, notably in terms of validity and valuation of the titles.

Progress in emerging technologies has advantaged from start-ups, which often have little assets other than their technology that they require to protect and use to raise capital. These companies help bring new ideas and innovations to the market.

OECD governments, following the Bayh-Dole Act of 1980 in the USA, have used IPR for leveraging the commercialization of inventions by universities which might otherwise have stayed on the shelves.

In order to achieve a balance, IPR policy should go beyond the design of the basic legal framework which defines rights and obligations of IPR owners: it should also develop instruments whose own flexibility would help the system work. Such a policy agenda means.

Reviewing exemptions to copyright in the light of the internet's different uses.

Clarifying exemptions for research use.

Promoting an active and open commercialization policy for universities.

Encouraging the commercialization and monetization of IPR: for example draft licensing contracts, valuation standards.

Standards: encouraging pooling mechanisms, platforms etc.

Accelerating patent processing while preserving quality (for example through international cooperation).

\section{Reforming product and labor market}

Policy reforms are required to strengthen innovation and productivity outcomes. Stimulating the business sphere for innovation is very important, as business is the key driver of innovation. Further liberalization of the services sphere and of network industries could foster stronger innovation in these sectors, which account for about $70 \%$ of GDP in OECD countries. More innovation-friendly regulation, combined with small barriers to trade and foreign investment would enhance competition and would foster the transfer of technology and knowledge across borders. Reform of labor markets, notably through well-designed employment legislation, would help companies to adjust and permit them to draw benefits from their investment in innovation.

OECD assessments have established a negative link between the restrictiveness of economic regulations in goods and labor markets, and productivity growth. In the goods markets limited competition among suppliers could increase the cost of inputs and make products supplied less innovative. It may discourage innovation, or make it costly to develop it or to defend the intellectual property. On the other hand, restrictive labor markets may restrict firms' ability to put in place the changes in the workforce and firm organization necessary to reap benefits from new technology deployed.

Moreover, OECD empirical analysis shows that competition-restraining regulations slow the rate of catch-up with the technological frontier, where labor productivity is the highest. By implication, countries may have achieved faster productivity growth over the 19952014 period if they had set their regulations in each nonmanufacturing sphere on the least constraining stance in the OECD space in that industry (OECD, 2007).

Financial markets reforming can also stimulate innovation and growth, including by helping to eliminate the financing gaps faced by some innovative small companies. It is suggested that industrial sectors that are dependent on finance tend to grow faster in economies that have better developed financial systems.

Besides, the sectors that tend to be the most dependent on external financial sources are the ones that invest 
the most in R\&D (pharmaceuticals, refined petroleum products and electronic equipment).

The market for the risk capital, particularly venture capital and less formal sources of finance such as business angels' funds play an important role in the innovation financing. Venture capital investment is small in most European countries as compared with North America, Great Britain and the Netherlands.

Investment of innovation would be supposed by more efficient venture capital markets and easier access to external finance. Differences in the availability and use of venture capital across countries may to some extent be rooted in different cultural attitudes towards entrepreneurship, but they also reflect policies that discourage risk-taking.

Improving disclosure of intellectual assets could help improve the allocation of capital. Competition in financial markets encourages firms to improve their reporting and practices on intellectual assets. Although, best practices have not been disseminated across firms and jurisdictions, and governments could encourage the transfer of best practices, already pioneered by advanced firms, in a principles-based manner (OECD, 2007).

\section{Importance of education system}

Innovation relies heavily on the creation of knowledge, through both education and science. A well-performing and accessible education system facilitates the diffusion of innovation. The contribution of education is well documented. Some of this occurs through science and innovation.

Investment in the education and highly skilled workers is an important factor in determining the contribution that research can make to scientific progress and innovation. Besides, human capital is a key factor in the adoption of modern technologies and the introduction of innovative practices.

Much of the latter operates through growth in MFP arising from managerial practices, organizational change and inventions per se. Growth of skills embodied in workers and managers play a key role in this process. Growth in output per employed person is attributable to increases in the human capital of those in employment.

Creating and diffusing new products and processes needs strong science and technology (S\&T) skills as well as many non-research soft and entrepreneurial skills. There is an increasing emphasis on policy issues connected with the availability of highly skilled labor, particularly highly skilled human resources in science and technology. Strong S\&T skills facilitate the uptake of new technologies which drives innovation throughout the economy. This places a premium on both the "quantity" as well as the quality of highly skilled labor in the economy.

But as, innovative activity may appear from any part of the production process, not only from the R\&D laboratory, "softer" or more intangible skills such as entrepreneurial ability, adaptability etc., also contribute to innovation, especially in services and in organizational innovation.
As a result, in some of the successful education systems there is now less emphasis on the reproduction of subject matter knowledge, which develops skills that are easiest to automatize and offshore, and more focus on evaluating skills in the context of real-world complexity, such as expert thinking - the ability to structure problems, learning strategies and self-concept.

Education policy makers are paying attention to innovation outcomes, and there is increasing emphasis to move towards a school environment which is less elitist between training for theoretical and practical understanding, and geared towards making a majority of students successful.

There is scrutiny of the efficiency of education systems throughout the OECD space, and a greater willingness to use international comparisons of outcomes in this area. As distinct from more spending in education as such, good education outcomes which can support a more innovative economy involve structural shifts in the way education is delivered, from uniformity in the system to individualizing learning, from a focus on provision to a focus on choice, from managing inputs to education towards devolving responsibilities and enabling outcomes, from talking about equity to delivery equity. On the latter aspect OECD data (OECD, 2004) show that many of the problems, in particular in Europe, originate from compartmentalized and stratified systems where learning outcomes depend on the social background of individuals and potential therefore goes wasted. The OECD 2007 report Going for Growth (OECD, 2006) identifies education reform (basic and tertiary, depending on the country) as a priority action area for 18 out of 30 countries.

\section{Public funding as a key factor of innovation policy}

Public investment in science plays an important role in developing ICT and other technologies and in enabling further innovation. Many fundamental innovations with deep and positive social impacts had their roots in public research and came from findings that were impossible to foresee. Fundamental innovations such as the World Wide Web and the Web browser emerged, not from competitive market processes, but from government-funded research held in universities, industry and government labs. Much of the R\&D was conducted as part of government programs, in some cases after the market had abandoned the research.

Reform of the funding of higher education and science institutions, by providing incentives that focus on excellence and relevance, can help strengthen the contribution of public investment to scientific progress and innovation. Better governance of universities and laboratories can be achieved through the use of new methods, such as greater use of project funding (contracts and grants awarded through competition) as opposed to institutional block grants, increases of funding for researches that are linked to economic needs, and the creation of research centers that serve both to concentrate expertise particularly 
fields of science and to foster research at the nexus of several disciplines. It also often requires a commitment to evaluating researchers and research institutes, as well as changes in the way such evaluations are conducted. Evaluation criteria must consider that excellence in research has become in some disciplines, more connected with industry applications and contributions to addressing social problems.

Although, the science system have not be made more responsive to identifiable opportunities at the expense of creativity in exploring the knowledge frontiers within a long time frame. Because changes in business strategies strengthen longstanding disincentives for private industry to invest in research, the need for government support rises. Securing support for fundamental knowledge and research is a priority for many governments, even if some have found it difficult. It is also imperative to safeguard knowledge with the aim to ensure the broad transfer of the results of publicly funded research.

More can also be done to link science and business, including by enhancing the climate for innovative business. Many OECD members lag behind in indicators of modernizing their science-innovation interface. Better management of IPRs in public institutes is important in order to develop relationships between public research and industrial innovation. Efforts are required to boost exchanges of tacit knowledge between the public and private sectors, through the movement of labor force, for example. Low rates of researcher mobility between the private and public sectors remain a big bottleneck to knowledge and technology flows in many countries. Regulatory reform related to labor mobility and licensing can be complemented by measures that promote business demand for scientific inputs and improve the ability of public research institutes to transfer knowledge and technology to the private sector. Policies to enhance science-industrybusiness relationships must be part of a strategy addressing the business sector's demand for the results of public research.

\section{Innovation and environmental challenges}

Innovation can contribute to meeting environmental and challenges, such as climate change, when the right incentives are given. The use of flexible instruments including taxes, emissions trading and technology-neutral performance standards should make incentives for innovation and foster the international transfer of clean technologies.

To take one example, innovation in energy technology is becoming important to meet demand for energy amidst concern about the security of energy supplies and calls for environmental protection. Governments across the OECD are investing enormous sums in $\mathrm{R} \& \mathrm{D}$ on new energy technologies, such as fuel cells, and seeking ways to smooth the transition to a more sustainable, economy. Recent OECD work on hydrogen fuel cells has reviewed national efforts in this sphere and has found that, innovative activity is on the rise. But the level of investment in energy-related $\mathrm{R} \& \mathrm{D}$ may need to rise further, thanks to the growing importance of renewable energy since the return of high oil prices and the environmental goal of shifting away from fossil fuels.

Strengthening innovation is regarded as a challenging policy goal. As it places a premium on higher level skills and may involve significant adjustment, it can be perceived as conflicting with social goals, including income distribution and employment creation. Indeed policies to strengthen innovation cannot be conceived and implemented in isolation.

Policy coordination is important - only a wide-ranging strategy to foster and strengthen innovation could help address social and environmental aims while building a foundation for future economic growth. Governance of policies towards innovation is important as innovation requires efforts from many government agencies, and from the national levels. Coordinating policies is important to avoid duplication of efforts and ensure a coherence of policies at different levels.

Innovation doesn't need to go at the cost of employment performance. Some countries that have emphasized innovation last years have experienced strong employment growth, showing that these can go hand in hand. In reality, several countries that have observed strong employment growth over the past decade, such as Spain and Ireland, are today emphasizing innovation as the scope for further employment-led growth is becoming more limited and growth will require coming from more rapid productivity growth, including innovation.

\section{Conclusions}

The investigation allows making some conclusions. The capability to innovate will be an important determinant of the global competitiveness over the future decade. There is awareness among politics that innovative activity is the main engine of economic progress as well as a potential factor in meeting global challenges in spheres such as the environment and health.

Governments can play an important role in enhancing innovation. Public investment in science and research can play a key role in developing ICT and other technologies and in enabling further innovation. This shows the importance of reforming the management and funding of investment in science and technologies, as well as public support to innovative activity in the private sector.

It is identified that rises in R\&D intensity and innovation are driven by such factors: reduction of anti-competitive market regulations, which promotes business $R \& D$ and strengthens the incentives for innovations; stable economic conditions and low interest rates which encourage the growth of innovation activity by creating a low-cost environment for investment in innovation; availability of internal and external finance.

It is given the basic legal framework which defines rights and obligations of IPR owners: reviewing exemptions to copyright in the light of the internet's different uses; clarifying 
exemptions for research use; promoting an active and open commercialization policy for universities; encouraging the commercialization and monetization of IPR: for example draft licensing contracts, valuation standards; standards: encouraging pooling mechanisms, platforms etc.; accelerating patent processing while preserving quality.

\section{References}

A strategy for American innovation. (2011). Retrieved September 4, 2015 from https://www.whitehouse.gov/ sites/default/files/uploads/InnovationStrategy.pdf

Innovation and growth. Rationale for an innovation strategy. (2007). Retrieved September 2, 2015 from http://www.oecd.org/science/inno/39374789.pdf

OECD (2007). Creating Value from Intellectual Assets, Policy Brief. (2007). Retrieved September 3, 2015 from http://www.oecd.org/berlin/41408747.pdf

OECD (2006). Main Science and Technology Indicators (MSTI) Retrieved September 5, 2015 from http://www.micit.go.cr/encuesta/docs/textos/ocde_indicadores_de_ciencia_tecnologia_e_innovacion_en_ mundo_en_cambio.pdf

OECD (2006). Going for Growth. Retrieved September 1, 2015 from http://www.oecd.org/eco/labour/36054358.pdf.

OECD (2007). Going for Growth 2007. Retrieved September 1, 2015 from http://www.oecd.org/eco/ labour/38088376.pdf

OECD (2004). Learning for Tomorrow's World. Retrieved September 2, 2015 from http://www.oecd.org/ education/school/programmeforinternationalstudentassessmentpisa/34002216.pdf

The Lisbon strategy 2000-2010. An analysis and evaluation of the methods used and result achieved. (2000). Retrieved September 5, 2015 from http://www.europarl.europa.eu/document/activities/ cont/201107/20110718ATT24270/20110718ATT24270EN.pdf

\section{Иван АНИСИМОВ}

\section{ОСОБЕННОСТИ ИННОВАЦИОННОЙ ПОЛИТИКИ В СТРАНАХ ОЭСР}

Аннотация. Целью статьи является анализ особенностей инновационной политики в странах ОЭСР и предложениебазовыхрекомендацийопределенияправиобязанностейсобственниковправинтеллектуальной собственности. Правительство играет важную роль в разработке политики, ориентированной на спрос: разумное регулирование, стандарты, обучение потребителей, налогообложение, государственный заказ. В силу того, что спрос и предложение взаимосвязаны, политика, влияющая на обе стороны вопроса, должна быть нацелена на перспективную инновационную деятельность и стабильный рост. Политика поддержки инноваций должна учитывать изменения международной экономики и трансформацию инновационных процессов. Трансформация изобретения в инновацию подразумевает широкий спектр видов деятельности. Инновационная деятельность сегодня включает больше видов деятельности, нежели НИОКР, хотя НИОКР также имеют большое значение. Методология. Данные для исследования взяты из публикаций и отчетов Европейской Комиссии, ОЭСР, Мирового Банка и т.д. Использованы методы общенаучного познания и качественного анализа. Результаты. Определено, что на рост интенсивности НИОКР и инноваций влияют следующие факторы: уменьшение антимонопольного рыночного регулирования, что стимулирует бизнес НИОКР и инновации; стабильные экономические условия и низкая процентная ставка, стимулирующая инновационную деятельность и инвестиции; доступность внешних и внутренних финансовых ресурсов. Практическое значение. Проведен анализ особенностей инновационной политики в странах ОЭСР и предложеныбазовыерекомендацииопределенияправиобязанностейсобственниковправинтеллектуальной собственности: пересмотр льгот на копирайт в свете разнообразия интернет - пользователей; установление льгот для пользователей результатами исследований; поддержка политики активной коммерциализации для университетов; стимулирование коммерциализации прав интеллектуальной собственности, например, разработка проектов лицензионных контрактов, стандартов оценивания, поддержка механизмов трансфера и т.д.; ускорение выдачи патентов с учетом проверки качества. Значение/оригинальность. Полученные в результате исследования выводы помогут понять особенности инновационной политики в странах ОЭСР, что даст возможность использовать их опыт в Украине. 